\title{
Perilaku Komunikasi Otaku dalam Interaksi Sosial (Studi Fenomenologi Pada Anggota Komunitas Jepang Soshonbu Bandung)
}

\author{
Sakinah Biiznilla Yulian1 \\ Program Studi S1 Ilmu Komunikasi \\ Fakultas Komunikasi dan Bisnis, Universitas Telkom, Bandung, Indonesia \\ nlikan12@gmail.com \\ Mohammad Syahriar Sugandi \\ Program Studi S1 Ilmu Komunikasi \\ Fakultas Komunikasi dan Bisnis, Universitas Telkom, Bandung, Indonesia \\ mohsyahriar@gmail.com
}

\begin{abstract}
Otaku is a term referring to those who fond of Japanese pop culture like anime and manga. Because of some activities, negative views on Otaku developed in the society. This causes Otaku to tend to experience difficulties in interacting with non-Otaku, then they create or join groups or communities that are in accordance with their vision and mission towards Japanese popular culture. With this communities Otaku can interact openly without fear of misunderstanding. This study aims to reveal Otaku's communication behavior in social interactions. This research method is qualitative research with a phenomenological approach and uses constructivism paradigm. Data collection techniques are carried out by interviews, observation and literatures. Based on the research result revealed that Otaku does some communication behavior in social interaction. In social interaction it produces an associative and dissociative process when Otaku interacting with both other Otaku and non-Otaku.
\end{abstract}

Keywords: Communication Behavior, Otaku, Social Interaction

\begin{abstract}
Abstrak. Otaku adalah orang yang menggemari budaya populer Jepang, seperti anime dan manga karena pandangan-pandangan kurang baik di masyarakat, Otaku cenderung mengalami kesulitan dalam berinteraksi dengan non-Otaku. Mereka lalu bergabung dengan komunitas yang sesuai dengan visi misi mereka. Dengan adanya komunitas itu mereka dapat berinteraksi dengan terbuka tanpa perlu takut akan munculnya kesalahpahaman. Riset ini bertujuan mengungkap perilaku Otaku dalam interaksi sosial. Metode penelitian ini adalah penelitian kualitatif dengan pendekatan fenomenologi dan menggunakan paradigma konstruktivisme. Teknik pengumpulan data dilakukan melalui wawancara, observasi, dan literatur. Riset ini menemukan bahwa Otaku melakukan perilaku komunikasi dalam interaksi berupa proses asosiatif dan disosiatif ketika berinteraksi baik dengan Otaku lainnya maupun non-Otaku.
\end{abstract}

Kata Kunci: Perilaku Komunikasi, Otaku, Interaksi Sosial

\footnotetext{
${ }^{1}$ Penulis Korespondensi 


\section{Pendahuluan}

Budaya populer Jepang (Japanese popular culture) telah berhasil menarik perhatian masyarakat internasional. Budaya populer Jepang adalah budaya yang berasal dari Negara Jepang yang dikenal, dinikmati, dan dikonsumsi oleh masyarakat dunia tak terkecuali masyarakat Indonesia.

Beberapa contoh budaya populer Jepang adalah manga dan anime. Manga adalah sebutan untuk komik dari Jepang. Manga punya bermacam jenis. Ia laris di pasaran baik di Jepang maupun di negaranegara lain. Anime yang merupakan animasi dari Jepang juga menarik perhatian banyak penonton di seluruh dunia.

Dari kedua produk kebudayaan Jepang tersebut, ada yang disebut sebagai Otaku. Otaku adalah istilah yang merujuk kepada seseorang, laki-laki atau perempuan, yang sangat menggemari budaya populer Jepang anime dan manga. Otaku merupakan istilah yang secara umum mengacu kepada kegemaran terhadap anime, manga, video games, computers, science fiction, special-effects films, anime figurines, dan sebagainya (Azuma, 2009:3).

Otaku seringkali dekat dengan makna yang negatif; orang yang tertutup. Asosiasi itu terutama sejak kasus Miyazaki, seorang Otaku yang menculik dan memerkosa empat anak perempuan di Jepang pada 1988. Sejak peristiwa itu, banyak media mengkonotasikan Otaku sebagai orang yang introvert atau manusia yang lebih berkaitan dengan dunia dalam pikiran manusia itu sendiri, cenderung menutup diri dari kehidupan luar. Bahkan, ada yang menganggap bahwa semua Otaku ada sosiopat seperti Miyazaki (Azuma, 2009: 4).
Otaku lalu merasa bahwa lingkungan sekitar mereka tidak mampu memahami dan mengerti identitas mereka sebagai Otaku. Ini menjadi salah satu alasan mereka, para Otaku, menarik diri dari kehidupan sosial.

Sebagai makhluk sosial, manusia punya kebutuhan untuk berinteraksi dan berkomunikasi dengan manusia lainnya. Tujuannya bisa macam-macam seperti untuk bertukar informasi pengalaman, ataupun membuat sebuah relasi dalam kehidupan sosial. Demikian juga seorang Otaku.

Adanya komunitas dan acara-acara kebudayaan Jepang merupakan hal yang sangat berguna bagi Otaku. Mereka dapat berinteraksi dengan terbuka tanpa perlu takut akan munculnya kesalahpahaman, juga merasa nyaman dengan lingkungan sekitarnya. Komunitas-komunitas ini pun juga saling berhubungan satu sama lain sehingga para Otaku pun dapat mengenal dan berinteraksi dengan Otaku lainnya yang ada di luar lingkungan mereka.

Komunitas Jepang Soshonbu (Association of Highschool Nihon no Kurabu) di Bandung merupakan komunitas Jepang pertama yang memiliki konsep organisasi semi formal dan berorientasi pada pendidikan. Soshonbu merupakan komunitas Jepang pertama kelas pelajar SMA di Kota Bandung. Komunitas ini bertujuan sebagai wadah untuk menyalurkan hobi, mengembangkan minat dan bakat, dan memperluas relasi sesama pecinta manga dan anime. Soshonbu juga sudah menjalin kerjasama dengan Dinas Pemuda dan Olahraga (Dispora) Kota Bandung.

Adanya komunitas ini mempermudah Otaku untuk membangun hubungan dengan individu lainnya, baik sesama Otaku ataupun bukan. Peneliti tertarik untuk mengamati bagaimana perilaku 
komunikasi komunitas Jepang Soshonbu dalam interaksi sosial, maka rumusan masalah penelitian ini adalah bagaimana perilaku komunikasi Otaku dalam interaksi sosial?.

Konsep interaksi sosial dalam penelitian ini dibagi menjadi dua sebagaimana Gillin dan Gillin (Bungin 2008: 58) kemukakan, yakni proses asosiatif dan proses disasosiatif.

Proses Asosiatif adalah adanya proses timbal balik yang terjadi antara orang per orang atau kelompok satu dengan lainnya, di mana proses ini menghasilkan pencapaian tujuan-tujuan bersama. Proses Disosiatif, di sisi lain, adalah proses perlawanan (oposisi) yang dilakukan oleh individu-individu dan kelompok dalam proses sosial di antara mereka pada suatu masyarakat.

Bentuk perilaku komunikasi Otaku dalam penelitian ini akan dibagi menjadi dua, yakni komunikasi verbal dan nonverbal.

Bagi akademisi, penelitian ini diharapkan dapat memberikan pengetahuan serta pemahaman lebih jauh dan mendalam dan sebagai bahan acuan juga referensi untuk penelitian yang berkaitan dan bagi masyarakat dengan adanya penelitian ini diharapkan dapat menambah pengetahuan masyarakat Indonesia mengenai perilaku komunikasi para Otaku dalam berinteraksi sosial.

\section{Metode Peneltian}

Peneliti menggunakan pendekatan kualitatif. Menurut Bodgan dan Taylor (1975), metode kualitatif adalah prosedur penelitian yang menghasilkan data deskriptif: ucapan atau tulisan dan perilaku yang dapat diamati dari orangorang (subjek). Pendekatan ini menunjukkan latar dan individu-individu dalam latar itu secara keseluruhan, tidak dipersempit menjadi variabel yang terpisah atau menjadi hipotesis, tetapi dipandang sebagai bagian dari suatu keseluruhan. (Ahmadi, 2014:15).

Dalam penelitian ini, penulis menggunakan strategi fenomenologi. Creswell (2015: 105) mendeskripsikan fenomenologi sebagai pemaknaan umum dari sejumlah individu terhadap berbagai pengalaman hidup mereka terkait dengan konsep atau fenomena. Fenomenologi melihat bahwa fenomena yang tampak merupakan objek yang penuh makna. Menurut pemikiran Schutz (Kuswarno, 2013: 18), fenomenologi adalah bagaimana memahami tindakan sosial melalui proses penafsiran.

Paradigma merupakan model yang membantu peneliti dalam merumuskan persoalan yang harus dijawab serta menginterpretasikan jawaban yang diperboleh. Harmon dalam Moleong (2012: 49) mengartikan paradigma sebagai kumpulan longgar dari sejumlah asumsi yang dipegang bersama, konsep atau preposisi yang mengarahkan cara berpikir dan penelitian.

Paradigma yang penulis gunakan dalam penelitian ini adalah paradigma konstruktivis. Menurut paradigma kontruktivisme, antara peneliti dan subjek yang diteliti, perlu tercipta empati dan interaksi dialektis agar mampu merekonstruksi realitas yang diteliti melalui metode kualitatif seperti observasi partisipasi. Subjek penelitian dalam penelitian ini, yaitu Otaku yang menjadi anggota aktif dalam Soshonbu. Objek penelitian yang digunakan adalah perilaku komunikasi Otaku dalam interaksi sosial.

Pengumpulan data dilakukan dengan wawancara mendalam dan observasi partisipatif. Sementara itu, analisis data menggunakan analisis data kualitatif. Bogdan dan Biklen (dalam Moleong 2014: 248) mengatakan analisis data kualitatif 
adalah upaya yang dilakukan dengan jalan bekerja dengan data, mengorganisasikan data, memilah-milahnya menjadi satuan yang dapat dikelola, mensistesiskannya, mencari dan menemukan pola, menemukan apa yang penting dan apa yang dipelajari, dan memutuskan apa yang dapat diceritakan kepada orang lain. Analisis data pada penelitian ini terdiri dari reduksi data, penyajian data, penarikan kesimpulan. Peneliti juga menggunakan metode triangulasi sumber dengan membandingkan dan mengecek sumbersumber, baik sumber primer maupun sekunder. Dengan menggunakan metode ini, dapat dibuktikan kenyataan yang sebenarnya pada informan (data primer), observasi lapangan, maupun literatur (data sekunder).

\section{Hasil Penelitian Dan Pembahasan}

Dalam analisis, peneliti membaca keseluruhan data yang didapat dari wawancara mendalam dan observasi di lapangan. Kemudian, peristiwa/pengalaman subjek penelitian dikategorisasikan sesuai dengan permasalahan yang diteliti.

\section{Komunikasi Verbal sesama Otaku}

\section{a. Asosiatif}

Otaku lebih nyaman dan terbuka ketika berinteraksi dengan sesama Otaku. Ini dikarenakan Otaku merasa bahwa sesama Otaku akan memahami satu sama lain. Apabila menemui orang yang sama kesukaannya, maka Otaku cenderung untuk terbuka dan bertukar pesan mengenai apa yang menyangkut hobi mereka seputar budaya populer Jepang.

Fungsi komunikasi, menurut Effendy dalam bukunya Ilmu Komunikasi Teori dan Praktik (2003: 55), adalah menginformasi (to inform), mendidik (to educate), menghibur (to entertaint), dan untuk mempengaruhi (to influence). Otaku berkomunikasi dengan empat tujuan tersebut.

Otaku saling memberi informasi satu sama lain. Informasi yang diberikan pun tidak berkutat mengenai budaya populer Jepang, tetapi juga sejarah, isu politik, isu yang sedang hangat, dan lain-lain.

Komunikasi Otaku juga bertujuan mendidik. Otaku saling memberi pengetahuan mengenai negara Jepang itu sendiri.

Otaku memiliki guyonan yang serupa sehingga dapat menghibur satu sama lain. Otaku juga dapat menghibur satu sama lain ketika saling membahas informasi mengenai adegan favorit atau adegan yang menarik dari anime.

Otaku juga dapat mempengaruhi satu sama lain. Terlihat ketika saling merekomendasikan anime yang bagus dan saat mengingatkan satu sama lain untuk tidak berperilaku menutup diri.

Adanya perilaku verbal informan dengan Otaku lainnya menimbulkan hubungan yang terjalin dekat antara sesama Otaku. Otaku lebih interaktif ketika sedang berkomunikasi dengan satu sama lain. Mereka saling melemparkan pendapat dan ide masing-masing baik dalam suasana formal maupun tidak formal. Mereka menunjukkan adanya kedekatan seperti seorang teman dengan saling memberikan informasi, mendidik, menghibur, dan mempengaruhi satu sama lain ketika melakukan interaksi. Topik yang dibahas juga beragam mulai dari seputar Jepang sampai isu global. Bahasa yang dominan digunakan adalah Bahasa Indonesia dengan menyerap beberapa kata dari Bahasa Jepang. 


\section{b. Disosiatif}

Disosiatif yang peneliti temukan dari interaksi komunikasi diantara anggota Otaku adalah disosiasi jenis konflik. Konflik antar-Otaku tidak dapat dihindari, beberapa informan mengaku pernah mengalami konflik satu sama lain.

Konflik atau perbedaan termasuk interaksi sosial yang bersifat disosiatif. Konflik yang peneliti temukan hanyalah perdebatan anime atau karakter yang dijagokan satu sama lain. Konflik yang ditemukan dalam bentuk saling bertukar argumen untuk memperlihatkan keunggulan karakter atau anime masing-masing dan tidak sampai kontak fisik.

\section{Komunikasi Verbal Otaku dengan Non-Otaku}

\section{a. Asosiatif}

Adanya perilaku verbal informan dengan non Otaku menimbulkan keterbatasan dalam berinteraksi. Hal ini juga menjadi penyebab hambatan dalam berinteraksi. Menurut Effendy (2003: 45), ada beberapa hal yang merupakan hambatan komunikasi, yaitu gangguan (noise), kepentingan, motivasi terpendam, dan prasangka. Dari wawancara, didapatkan kepentingan dan prasangka yang akan diuraikan sebagai berikut.

- Kepentingan. Ini membuat seseorang menjadi selektif dalam menanggapi pesan. Otaku akan memilah informasi yang akan ditanggapi sesuai dengan kebutuhannya saja.

- Prasangka. Ini merupakan salah satu hambatan bagi suatu kegiatan komunikasi. Otaku merasa non Otaku tidak menerima buah pikir dirinya, begitu pula sebaliknya Otaku merasa tidak satu pemikiran dengan nonOtaku.
Terdapat perubahan yang dirasakan Otaku ketika bergabung di Soshonbu, yaitu tidak hanya dengan sesama Otaku tetap mereka juga berusaha berkomunikasi dalam interaksi sosial dengan non-Otaku. Perlahan Otaku yang menjadi anggota Soshonbu juga memiliki teman dekat di luar Soshonbu dan bukan Otaku.

Adanya perilaku verbal informan dengan non-Otaku memiliki keterbatasan dalam berinteraksi. Hal ini juga menjadi penyebab hambatan dalam berinteraksi. Namun, hal itu yang ingin diubah oleh anggota Soshonbu bahwa Otaku juga dapat berbaur seperti manusia pada umumnya. Perilaku verbal informan dengan nonOtaku memiliki keterbatasan dalam berinteraksi. Hal ini juga menjadi penyebab hambatan dalam berinteraksi. Namun, hal itu yang ingin diubah oleh anggota Soshonbu bahwa Otaku juga dapat berbaur seperti manusia pada umumnya.

\section{b. Disosiatif}

Proses disosiatif yang terjadi di Otaku dengan non-Otaku juga cenderung bersifat konflik. Konflik biasa terjadi akibat stigma negatif yang ada di masyarakat. Informan sering menerima julukan Otaku yang mana di sini Otaku memiliki makna yang negatif. Seperti kata Febrian selaku informan keenam, ketika menerima 'ejekan' tersebut, Otaku cenderung membiarkan hal tersebut dan tidak mempermasalahkan. Hambatan komunikasi juga terjadi di proses disosiatif. Otaku memiliki kecendrungan untuk diam dan tidak menggubris hal tersebut. Namun, ditemukan di beberapa kondisi membela dirinya bagaimana Otaku menurut pandangannya, apa itu sebenarnya anime atau manga. Ini dilakukan Otaku ketika ia sudah 'sangat' tersinggung saat menerima ejekan tersebut. Otaku melakukan pembenaran dan pembelaan diri untuk membuktikan bahwa hal-hal negatif tersebut tidak benar adanya dan Otaku 
bukanlah seseorang yang pantas untuk menerima stigma negatif tersebut.

\section{Komunikasi Non Verbal Otaku Sesama Otaku}

Komunikasi non verbal, menurut Duncan (Rakhmat, 2011: 285), ada enam jenis, yaitu kisenik atau gerakan tubuh, paralinguistik atau suara, prosemik atau penggunaan ruangan personal dan sosial, olfaksi atau penciuman, sensitivitas kulit, dan faktor artifaktual seperti pakaian dan kosmetik. Dalam penelitian ini, ada satu komunikasi non verbal yang ditunjukkan oleh informan dari enam jenis komunikasi non verbal menurut Duncan, yaitu Kisenik atau gerakan tubuh. Kisenik atau gerak tubuh yang peneliti temui adalah facial dan gestural. Perilaku non verbal mempunyai fungsi-fungsi sebagai berikut.

- Perilaku non verbal dapat mengulangi perilaku verbal.

- Memperteguh, menekankan atau melengkapi perilaku verbal.

- Perilaku non verbal dapat menggantikan perilaku verbal.

- Perilaku non verbal dapat meregulasi perilaku verbal.

- Perilaku non verbal dapat membantah atau bertentangan dengan perilaku verbal (Mulyana, 2013: 350).

\section{a. Asosiatif}

Pada facial, informan menunjukkan komunikasi non verbalnya. Komunikasi non verbal ini mereka gunakan untuk mendukung setiap kata dan situasi yang didapatkan oleh informan. Semua informan menunjukkan ekspresi wajah yang berbeda-beda tergantung pada apa yang ingin mereka ungkapan. Ekspresi tertawa Otaku tunjukkan ketika guyonan yang dikeluarkan satu sama lain diterima, juga ketika mereka membahas adegan anime yang lucu. Fungsi yang muncul di sini adalah melengkapi perilaku verbal. Semua informan juga menunjukkan ekspresi yang senang saat membahas anime.

Mengganti perilaku verbal juga muncul ketika Otaku setuju akan suatu pernyatan. Mereka akan mengangguk yang mengindikasikan pengakuan atau menyetujui.

Selain facial, peneliti juga melihat gestural tubuh yang dilakukan oleh informan. Ini dilakukan seperti melakukan gerakan tangan untuk memperagakan adegan yang ada di anime, bagaimana Gundam mengeluarkan senjatanya juga bagaimana transformasi yang dilakukan Gundam. Lainnya seperti memperagakan gerakan tangan Naruto saat mengeluarkan jurus. Hal ini dilakukan ketika mereka ingin melengkapi atau menggantikan perilaku verbal.

Peneliti menyimpulkan bahwa Otaku lebih ekspresif saat berinteraksi dengan Otaku lainnya. Otaku merasa nyaman saat mengeluarkan ekspresiekspresi dengan sesama Otaku. Gestural yang dimunculkan pun sesuai dengan anime atau manga yang disenangi.

\section{b. Disosiatif}

Sama halnya dengan proses asosiatif, pada proses disosiatif pun, Otaku leluasa untuk mengekspresikan komunikasi mereka. Saat dalam konflik pun Otaku memperlihatkan beberapa komunikasi non verbal. Seperti facial, mereka memperlihatkan mata melotot dan alis yang naik, ketika perdebatan antara karakter atau anime siapa yang terbaik. Facial yang diperlihatkan memperteguh perilaku verbal.

Otaku juga melakukan beberapa gestural seperti memperlihatkan telapak tangan atau menunjuk ke arah smartphone untuk memperlihatkan informasi yang 
memperkuat argumen mereka. Ini dilakukan saat Otaku ingin mempertegas argumen-argumen mereka.

Peneliti menyimpulkan bahwa Otaku lebih leluasa untuk mengekspresikan komunikasi mereka. Ini dilakukan dengan memperlihatkan telapak tangan atau menunjuk ke arah smartphone untuk memperlihatkan informasi yang memperkuat argumen mereka. Ini dilakukan saat Otaku ingin mempertegas argumen-argumen mereka atau mata melotot dan alis yang naik. Ini terjadi saat perdebatan antara karakter atau anime siapa yang terbaik.

\section{Komunikasi Non Verbal Otaku dengan Non-Otaku}

Berbeda ketika Otaku berinteraksi dengan non-Otaku. Mereka cenderung pasif dan tidak terlalu memperlihatkan banyak ekspresi juga gestur tubuh.

\section{a. Asosiatif}

Saat berkomunikasi dengan nonOtaku, ekspresi facial yang diperlihatkan Otaku tidak terlalu signifikan. Mereka hanya memperlihatkan ekspresi tertawa dan senyum kecil. Terlebih beberapa juga memilih untuk tidak mengeluarkan ekspresi sama sekali. Ketika ada guyonan Otaku tertawa tanpa memberi tanggapan.

Gestural yang diperlihatkan juga tidak terlalu signifikan. Otaku melakukan gerakan tubuh yang diperlukan saja. Otaku juga tidak terlalu merespon atau menanggapi interaksi dari non-Otaku.

Dari wawancara dengan informan, peneliti menarik kesimpulan bahwa saat berinteraksi dengan non-Otaku, Otaku cenderung pasif dalam mengekspresikan komunikasi nya. Ia tidak melakukan banyak gerakan yang signifikan saat berinteraksi. Perilaku non verbal yang ditunjukkan cenderung berfungsi untuk mengganti perilaku verbal.

\section{b. Disosiatif}

Tidak jauh berbeda dengan proses asosiatif, saat merasa diganggu Otaku lebih memilih hanya sekadar melirik dan tidak menggubris hal yang mengganggunya tersebut. Ia juga tidak memperlihatkan ekspresi sedih atau kesal. Otaku juga menghindari kontak mata dengan lawan bicara.

Gestural yang diperlihatkan Otaku cenderung menghindari interaksi. Mereka kerap menundukkan kepala fokus dengan smartphone-nya saat dikerumunan ramai dan menggunakan headset. Henokh, misalnya, yang merupakan informan pertama, saat mengikuti Henokh menuju tempat wawancara Henokh kebanyakan menunduk dan memperhatikan smartphone-nya. Hal ini juga dilakukan oleh Ney selaku informan keempat. Ia lebih memilih untuk memainkan permainan di smartphone-nya saat sedang menunggu informan lainnya datang. Semua informan pun diketahui tengah menggunakan headset saat dalam perjalanan menuju tempat yang sudah ditentukan untuk wawacara.

Peneliti menyimpulkan bahwasanya Otaku cenderung menghindari interaksi dengan non-Otaku. Hal ini dapat dilihat dari beberapa gerakan tubuh seperti facial yang menghindari tatap mata, dari gestural yang fokus dengan smartphone masing-masing dan menggunakan headset saat berada dikerumunan ramai.

\section{Kesimpulan dan Saran}

Dalam Proses Asosiatif interaksi yang terjadi Otaku menjadi leluasa ketika berkomunikasi dengan sesama Otaku. Ia merasa nyaman untuk mengeluarkan buah pikir bersama seseorang yang sepemahaman dengannya. Topik yang dibicarakan juga beragam, tidak berkutat di satu 
pembicaraan saja. Fungsi komunikasi yang terjadi juga terpenuhi yaitu saling bertukar informasi, memberikan edukasi, komunikasi juga dapat menjadi hiburan, dan dapat saling mempengaruhi satu sama lain.

Berbeda halnya ketika Otaku berinteraksi dengan non-Otaku. Mereka lebih banyak menjadi pendengar dibanding menjadi pembicara. Topik yang diutarakan hanya bersifat informatif saja, seperti membahas tentang pekerjaan dan tugas sekolah, dimana topik ini merupakan suatu keharusan saat menjadi pelajar SMA. Otaku juga mengalami hambatan ketika berinteraksi dengan non-Otaku dikarenakan kepentingan dan prasangka. Namun, Otaku yang tergabung dalam Soshonbu perlahan mengalami perubahan dalam berkomunikasi dengan non-Otaku dimana beberapa informan mereka lebih membuka diri dalam berkomunikasi. Dengan tujuan menghilangkan stigma negatif yang menyebar di masyarakat informan satu sama lain saling mengingatkan untuk membuka diri dengan non-Otaku .

Perbedaan pendapat merupakan hal yang sudah lumrah saat berinteraksi, dan hal ini pun terjadi pada Proses Disosiatif saat berinteraksi. Konflik yang muncul seputar perdebatan karakter atau anime kesukaan siapa yang paling menarik. Saat perdebatan ini pun sesama Otaku saling melemparkan argumenargumen milik mereka, untuk meyakinkan lawan bahwa karakter atau anime yang disukainya lah yang terbaik. Ini jarang terjadi ketika sedang berinteraksi dengan non-Otaku. Konflik cenderung muncul ketika non-Otaku memanggil atau memberi julukan Otaku kepada seseorang, yang mana Otaku ini memiliki nilai negatif. Namun, Otaku tidak mengambil aksi atau memberi tanggapan ketika hal ini terjadi dan lebih memilih untuk diam seakanakan tidak ada hal yang terjadi. Otaku akan memulai membela diri dan memberi pembenaran jika hal tersebut diperlukan di beberapa situasi seperti muncul dari orang terkasih, yaitu keluarga, atau ketika ledekan tersebut sudah berkali-kali dan semakin mengganggu Otaku tersebut. Berbeda ketika sesama Otaku saling melemparkan julukan Otaku. Julukan Otaku tersebut mengindikasikan sesama atau setipe, Otaku tidak menganggap julukan tersebut negatif.

Proses Asosiatif pada perilaku non verbal yang muncul condong mengarah ke facial atau ekspresi wajah dan gestural atau gerak tubuh. Sama halnya dengan komunikasi verbal, Otaku lebih banyak mengeluarkan ekspresi atau gerak tubuh saat berinteraksi dengan sesama Otaku. Ini dikarenakan Otaku tidak merasa ada yang salah dengan ekspresi atau gerakan tubuh yang diperlihatkan oleh Otaku lain. Saling memahami atau dalam satu pemahaman menjadi peneybab Otaku lebih terbuka satu sama lain dibandingkan saat bersama non-Otaku. Otaku lebih ekspresif saat berinteraksi dengan sesama Otaku.

Saat berinteraksi dengan nonOtaku, ekspresi dan gerakan tubuh yang dimunculkan berupa gerakan yang dibutuhkan. Di sini, tidak terlihat keantusiasan ketika berinteraksi dengan non-Otaku. Seperti contoh lelucon yang dikeluarkan oleh non-Otaku, Otaku akan ikut tertawa, tetapi bukan tertawa yang lepas, melainkan bentuk tertawa yang kecil bahkan hanya sekadar tersenyum. Otaku belum bisa terbuka ketika berinteraksi dengan non-Otaku.

Dalam Proses Disosiatif, ketika konflik terjadi, Otaku cenderung menunjukkan ekspresi marah yaitu mata melotot dan alis yang naik, saat sedang memberi argumen pun Otaku hanya mengeluarkan gerakan yang diperlukan untuk mempertegas dan memperkuat argumen tersebut. Otaku tidak melakukan kontak fisik ketika konflik terjadi. 
Ketika dalam suasana keramaian seperti di mall yang banyak orang tidak dikenal, Otaku cenderung memilih untuk menggunakan headset atau sibuk melakukan aktivitas seperti memainkan smartphone dengan kepala menunduk. Ini dilakukan untuk menghindari kemungkinan terjadinya percakapan. Ketika ada konflik yang terjadi seperti seseorang yang non-Otaku menjulukinya seorang Otaku. Maka Otaku lebih memilih diam, tidak mengeluarkan reaksi apapun, dan bertindak seakan-akan hal itu tidak mengganggunya sama sekali.

Hasil penelitian ini dapat menjadi referensi dalam penelitian selanjutnya yang melibatkan aspek perilaku komunikasi, khususnya perilaku komunikasi
Otaku. Bagi peneliti Ilmu Komunikasi, perlu kiranya melakukan penelitian mendalam bagaimana perilaku komunikasi yang dilakukan Otaku dalam interaksi sosial guna mengetahui bagaimana perilaku-perilaku yang dimunculkan Otaku lainnya selain perilaku yang sudah diteliti oleh peneliti.

Dalam ranah praktis, penelitian ini diharapkan dapat mereduksi stigma negatif yang berkembang di masyarakat. Penelitian ini membuktikan bahwa Otaku juga mengembangkan gaya komunikasi sebagaimana masyarakat biasanya. Penelitian ini juga membuktikan bahwa Otaku punya kemampuan untuk membuka diri yang dapat mengurangi stigma negative pada Otaku.

\section{Daftar Pustaka}

Ahmadi, Rulam. (2014). Metode Penelitian Kualitatif. Yogyakarta: Ar-Ruzz Media.

Azuma, Hiroki. (2009). Otaku Japan's Database Animals. Minneapolis: University of Minnesota.

Bungin, Burhan. (2008). Sosiologi Komunikasi. Jakarta: Kencana.

Creswell, J.W. (2015). Research Design Pendekatan Kualitatif, Kuantitatif, dan Mixed. Yogyakarta: Pustaka Pelajar.

Effendy, O.U. (2003). Ilmu, Teori dan Filsafat Komunikasi. Bandung: Citra Aditya Bakti.

Kuswarno, E. (2013). Metode Penelitian Komunikasi Fenomenologi. Bandung: Widya.

Moleong, L.J. (2012). Metode Penelitian Kualitatif. Bandung: PT Remaja Rosdakaya.
Moleong, L.J. (2014). Metode Penelitian Kualitatif. Bandung: PT Remaja Rosdakarya.

Mukminin, Ferri Amiril. 2016. Soshonbu, Komunitas Jepang yang Tak Hanya Asyik Berkumpul.

http://jabar.tribunnews.com/2016/ 10/23/soshonbu-komunitas-jepangyang-tak-hanya-asyik-berkumpul.

Diakses pada tanggal 10 September 2018 pukul 17:11 WIB.

Mulyana, D. (2013). Ilmu Komunikasi Suatu Pengantar. Bandung: Remaja.

Rakhmat, Jalaluddin. (2011). Psikologi Komunikasi. Bandung: PT Remaja Rosdakarya. 
Jurnal komunikasi, Volume 13, Nomor 2, April 2019, Hal 191-200 